\title{
INTENSITAS BERMAIN GAME ONLINE TERHADAP POLA AKTIVITAS FISIK SISWA SMP ADVENT MENIA, KABUPATEN SABU, RAI JUA, NTT
}

\author{
ONLINE GAME INTENSITY ON THE PHYSICAL ACTIVITY PATTERN OF ADVENT MENIA \\ MIDDLE SCHOOL STUDENTS, SABU RAI JUA DISTRICT, NTT
}

\author{
David Raymond Ludji Leo \\ davidraymondludjileo@gmail.com \\ Fakultas IImun Keperawatan, Universitas Advent Indonesia
}

\begin{abstract}
ABSTRAK
Pendahuluan: Kecanduan game online dapat mempengaruhi kesehatan fisik, hubungan sosial, menimbulkan kelemahan fisik sebagai akibat berkurangnya jam tidur, gizi yang tidak seimbang dan dapat mengakibatkan dehidrasi. Serta malas melakukan aktivitas fisik seperti berolahraga. Tujuan: Penelitian ini bertujuan untuk mengkajin pengaruh intensitas bermain game online terhadap pola aktivitas fisik siswa. Metode: Penelitian ini merupakan penelitian deskriptif korelasi dengan populasi siswa SMP Advent Menia, Kabupaten Sabu Rai Jua, NTT yang berjumlah 46 siswa dan sample direkrut dengan tehnik sampling jenuh. Hasil: data menunjukkan bahwa $80 \%$ berada pada kategori intensitas bermain game online yang rendah dan $20 \%$ pada kategori sedang. $80 \%$ memiliki pola aktivitas fisik yang rendah dan $20 \%$ memiliki pola aktivitas fisik sedang. terdapat hubungan yang signifikan antara intensitas bermain game online dengan pola aktivitas fisik. Diskusi: Asuhan keperawatan komunitas dalam pencegahan obesitas dan kecanduan game online pada remaja dapat menjadi pertimbangan dalam pelayanan kepada masyarakat serta focus dari penelitian berikutnya.
\end{abstract}

Kata kunci: Aktifitas fisik, Game online, intensitas

\section{ABSTRACT}

Introduction: Addiction to online games can affect physical health, social relations, cause physical weakness as a result of reduced sleep hours, uneven nutrition and can lead to dehydration. And lazy to do physical activities such as sports. Objective: This study aims to assess the effect of the intensity of playing online games on the patterns of physical activity of students. Methods: This study was a descriptive correlation study with the population of Advent Menia Junior High School students, Sabu Rai Jua District, NTT totaling 46 students and the sample was recruited with saturated sampling techniques. Results: data shows that $80 \%$ are in the low intensity category of online game play and $20 \%$ in the moderate category. $80 \%$ have low physical activity patterns and $20 \%$ have moderate physical activity patterns. There is a significant relationship between the intensity of playing online games with physical activity patterns. Discussion: Community nursing care in the prevention of obesity and addiction to online games in adolescents can be a consideration in service to the community and the focus of subsequent research.

Key words: Intensity, Physical activity, Online games,
JURNAL

\section{SKOLASTIK}

KEPERAWATAN

VOL. 6 , NO. 1

Januari - Juni 2020

ISSN: $2443-0935$

E-ISSN 2443 - 16990 


\section{PENDAHULUAN}

Pada jaman sekarang ini banyak orang khususnya kelompok usia remaja memainkan game online sebagai hiburan dan gantinya melakukan permainan yang melibatkan aktivitas fisik. Survei yang dilakukan Asosiasi Penyelenggara Jasa Internet Indonesia (APJII) (2014) mengemukakan bahwa dalam kurun waktu 10 tahun terakhir, game online memiliki peminat yang terus meningkat. Hal ini dapat terlihat dari semakin maraknya game center tersebar yang ada di kota-kota besar maupun kota-kota kecil.

Game online, meskipun dapat digunakan sebagai sarana rekreasi namun dapat juga berdampak buruk bagi remaja penggunanya. Pengguna game online seringkali mengalami adiksi, ditandai dengan bermain >4-5 jam perhari dan lebih mementingkan bermain game dari pada aktivitas lain. Dengan situasi ini maka timbul konflik yang disebabkan oleh pengabaian tugas-tugas peran sosial, tugas pekerjaan dan pendidikan serta aktifitas fisik dalam keseharian.

Langkah pertama yang perlu dilakukan dalam keperawatan komunitas untuk membantu pada remaja dalam mencegah dan mengatasi kondisi kecanduan online game maka dibutuhkan prose pengkajian yang baik. Dengan diperolehnya data-data dari pengkajian maka perawat dapat menegakkan diagnose kepertawatan serta menetapkan perencanaan keperawatan. Penelitian ini melihat perlunya kajian yang baik terhadap para siswa SMP yang sudah mulai mengenal dan bahkan memasuki tahap-kecanduan bermain online game.

\section{METODE}

Penelitian ini merupakan penelitian deskrptif korelasional yang bertujuan untuk mengkaji hubungan antara intensitas bermain game online terhadap pola aktivitas fisik siswa
SMP Advent Menia, Kabupaten Sabu Raijua, NTT.

Perilaku bermain game online serta pola aktivitas fisik remaja dikaji dengan menggunakan lembar kaji kecanduan game online (online game addiction) serta Physical Activity Questionnaire for Adolescents (PAQA). Kuesioner kecanduan terhadap game online terdiri atas 7 butir pertanyaan dengan beberapa alternatif pilihan jawaban. Alat ukur ini merupakan modifikasi dari Online Game Addiction yang telah diadopsi ke dalam bahasa Indonesia (Tjibeng, 2013). Kuesioner ini terdiri dari beberapa parameter diantaranya salience, excessive use, neglect work, anticipation, lack of control, dan neglect social life. Skala kecanduan menggunakan skala likert. Setiap item memiliki alternatif pilihan jawaban dengan skor nol sampai lima. Jika responden memilih jawaban jarang mendapat skor 1 , kadang-kadang mendapat skor 2, sering mendapat skor 3, sangat sering mendapat skor 4, selalu mendapat skor 5 (Tjibeng, 2013).

Lembar kaji pengukuran aktivitas remaja yang akan digunakan adalah Physical Activity Questionnaire for Adolescents (PAQ$A)$. terdapat 9 butir pertanyaan yang telah dimodifikasi dan disesuaikan dengan aktivitas siswa di Indonesia. Masing-masing butir pertanyaan memiliki alternatif pilihan jawaban yang akan diberi skor 1 = sangat tinggi sampai 5 = sangat rendah, serta 2 butir pertanyaan tambahan tentang berat dan tinggi badan. Erwinanto (2017), dalam penelitiannya, telah melakukan uji validitas dan reabilitas terhadap kuesioner pengukuran aktivitas remaja (PAQ-A) yang telah dimodifikasi dengan hasil koefisien Cronbach's Alpha sebesar 0,721 dan hasil validitas 0,361 . Sedangkan untuk kuesioner skala kecanduan game online didapatkan hasil koefisien validitas ( $r$ ) berkisar dari 0,29 sampai dengan 0,55 (Ibrahim, 2019). 


\section{HASIL}

Dari Tabel 1 dapat dilihat bahwa mayoritas catatan waktu bermain game online terpanjang adalah selama 2 jam sebanyak $37,5 \%$, mayoritas rata-rata hari per minggu untuk bermain game online adalah 2-3 hari per minggu sebanyak $67,5 \%$, jumlah waktu rata-rata per hari bermain game online adalah 3 jam per hari sebanyak 52,5\%, dan pengeluaran bulanan untuk game online adalah Rp. 65.000,- per bulan sebanyak $67,5 \%$.

Tabel 1. Demografi Responden

\begin{tabular}{lcc}
\hline \multicolumn{1}{c}{ Kategori } & $\mathrm{N}$ & $\%$ \\
\hline Catatan waktu terpanjang bermain game online & 13 & 32.5 \\
1 jam & 15 & 37.5 \\
2 jam & 12 & 30 \\
\hline jam & 40 & 100 \\
\hline Total & 0 & \\
\hline Rata-rata hari per minggu bermain game online & 27 & 0 \\
1 hari/minggu & 0 & 07.5 \\
2-3 hari/minggu & 13 & 32.5 \\
4-5 hari/minggu & 40 & 100 \\
6-7 hari/minggu & & \\
\hline Total & 2 & 5 \\
\hline Rata-rata jam per hari bermain game online & 17 & 42.5 \\
1 jam & 21 & 52.5 \\
2 jam & 40 & 100 \\
3 jam & & \\
Total & 27 & 67.5 \\
\hline Pengeluaran bulanan untuk game online & 13 & 32.5 \\
\hline Rp. 65.000,- $85.000,-$ & 40 & 100 \\
\hline Total & & \\
\hline
\end{tabular}

Berdasarkan Tabel 2 menunjukan bahwa untuk aspek pertama, yaitu salience atau bermain game online menjadi paling penting dan mendominasi pikiran individu. Sebanyak $87,5 \%$ responden berada pada kategori jarang, $10 \%$ pada kategori kadang-kadang, dan $2,5 \%$ pada kategori selalu.

Untuk aspek yaitu tolerance atau peningkatan jumlah bermain game online, $92,5 \%$ responden berada pada kategori jarang dan $7,5 \%$ berada pada kategori kadang-kadang. Toleransi sudah cukup diteliti terkait kecanduan zat psikoaktif dan cukup bukti menunjukkan bahwa fenomena tersebut dapat terjadi dalam perjudian dan gangguan internet gaming. Namun, perlu dicatat bahwa saat ini terdapat potensi perdebatan dimana berdasarkan penelitian yang mengandalkan laporan diri, bahwa berbagai perilaku yang berpotensi berlebihan (misalnya, menari, berbelanja) ditandai oleh gejala toleransi. Namun, tidak mungkin untuk menegaskan kesimpulan yang benar-benar pasti mengenai keberadaan toleransi berkenaan dengan perilaku spesifik kecuali didukung oleh buktibukti neurobiologis misalnya, perubahan / kepekaan dalam sirkuit organ otak yang tertentu (Billieux, Maurage, LopezFernandez, Kuss, \& Griffiths , 2015).

Untuk aspek mood modification atau strategi koping individu, 92,5\% responden berada pada kategori jarang dan 7,5\% berada dalam kategori kadang-kadang. Ini merujuk kepada 
pengalaman subyektif individu (sering dialami secara positif) yang digambarkan sebagai konsekuensi dari terlibat dalam aktivitas tertentu yaitu, mereka mengaku mengalami suatu perasaan semangat atau secara paradoks perasaan penenang dan / atau dapat memiliki manfaat menghilangkan stres atau "melarikan diri" atau "mati rasa"). Pada dasarnya, banyak pecandu menggunakan zat dan perilaku kecanduan lainnya sebagai cara untuk menghasilkan perubahan yang dapat diandalkan dan konsisten dalam suasana hati mereka sebagai strategi untuk "mengobati diri sendiri" dan membuat mereka merasa lebih baik dalam proses tersebut.

Untuk aspek kekambuhan, sebanyak 97,5\% responden berada pada kategori jarang dan $2,5 \%$ berada dalam kategori kadangkadang. Kekambuhan merujuk kepada kecenderungan untuk berulang kembali ke pola sebelumnya dari aktivitas tertentu untuk kambuh dan bahkan untuk pola yang paling ekstrim khas ketinggian kecanduan akan segera dipulihkan setelah bertahun-tahun pantang atau kontrol. Contoh klasik dari perilaku kambuh adalah pada perokok yang sering menyerah untuk jangka waktu tertentu dan kemudian kembali merokok penuh waktu setelah mencoba beberapa batang rokok. Namun kekambuhan seperti itu biasa terjadi pada semua kecanduan termasuk kecanduan perilaku, seperti perjudian (Griffiths, 2002).

Pada aspek withdrawal atau menarik diri dimana mengalami perasaan yang tidak menyenangkan bila waktu bermain game online dikurangi, sebanyak $87,5 \%$ responden berada pada kategori jarang, $10 \%$ responden dalam kategori kadangkadang, dan 2,5\% pada kategori sering. Dalam kasus Internet Gaming Disorder (IGD), gejala withdrawal mungkin dialami individu ketika aktivitas gaming diambil. Dalam kasus IGD tertentu, gejala-gejala ini biasanya digambarkan sebagai lekas marah, cemas, atau sedih, tetapi tidak ada tandatanda fisik penarikan farmakologis seperti pada gangguan penggunaan zat (American Psychiatric Association [APA], 2013).

Tabel 2. Frekuensi Aspek-aspek Intensitas Bermain Game Online

\begin{tabular}{lcccccccccc}
\hline $\begin{array}{l}\text { Aspek-aspek intensitas } \\
\text { bermain game online }\end{array}$ & \multicolumn{2}{c}{ Jarang } & \multicolumn{3}{c}{$\begin{array}{c}\text { Kadang- } \\
\text { kadang }\end{array}$} & \multicolumn{2}{c}{ Sering } & \multicolumn{2}{c}{$\begin{array}{c}\text { Sangat } \\
\text { sering }\end{array}$} & Selalu \\
\cline { 2 - 13 } & $\mathrm{N}$ & $\%$ & $\mathrm{~N}$ & $\%$ & $\mathrm{~N}$ & $\%$ & $\mathrm{~N}$ & $\%$ & $\mathrm{~N}$ & $\%$ \\
\hline Salience & 35 & 87,5 & 4 & 10 & 0 & 0 & 0 & 0 & 1 & 2, \\
& & & & & & & & & & 5 \\
Tolerance & 37 & 92,5 & 3 & 7,5 & 0 & 0 & 0 & 0 & 0 & 0 \\
Mood Modification & 37 & 92,5 & 3 & 7,5 & 0 & 0 & 0 & 0 & 0 & 0 \\
Kekambuhan & 39 & 97,5 & 1 & 2,5 & 0 & 0 & 0 & 0 & 0 & 0 \\
Withdrawal & 35 & 87,5 & 4 & 10 & 1 & 2,5 & 0 & 0 & 0 & 0 \\
Conflict & 39 & 97,5 & 1 & 2,5 & 0 & 0 & 0 & 0 & 0 & 0 \\
Lack of Control & 34 & 85 & 5 & 12,5 & 1 & 2,5 & 0 & 0 & 0 & 0 \\
\hline
\end{tabular}

Untuk aspek conflict atau masalah yang diakibatkan terlalu banyaknya menghabiskan waktu untuk game online, $97,5 \%$ responden berada pada kategori jarang dan $2,5 \%$ dalam kategori kadangkadang. Hal ini merujuk pada konflik antara pecandu dengan orang-orang di sekitar (konflik antar pribadi) atau dari dalam diri mereka sendiri (konflik intrapsikis) yang berkaitan dengan kecanduan aktivitas tertentu. Pemilihan kesenangan jangka pendek yang berkesinambungan mengarah pada pengabaian konsekuensi yang merugikan serta memiliki akibat kerusakan jangka panjang, yang pada gilirannya meningkatkan kebutuhan nyata akan aktivitas kecanduan sebagai strategi mengatasi masalah. Konflik dalam 
kehidupan pecandu berarti bahwa mereka akhirnya mengorbankan (i) hubungan pribadi mereka (misalnya, pasangan, anak-anak, kerabat, teman, dII.), (li) kehidupan belajar atau pendidikan (tergantung pada usia mereka), dan (iii) kegiatan sosial dan rekreasi lainnya. Konflik intra-psikis juga dapat dialami dalam bentuk pecandu mengetahui bahwa mereka sangat terlibat dalam perilaku dan ingin mengurangi atau menghentikan - tetapi menemukan mereka tidak dapat melakukannya karena mereka mengalami kehilangan kontrol yang subjektif yang pada gilirannya mungkin difasilitasi karena keinginan orang tersebut untuk secara sengaja menghindari atau mengurangi gejala penarikan potensial yang dihasilkan dari penghentian atau pengurangan perilaku.

Untuk aspek lack of control atau kurang mampu mengontrol waktu bermain game online, sebanyak $85 \%$ responden berada pada kategori jarang, 12,5\% dalam kategori kadang-kadang, dan 2,5\% pada kategori sering. Secara keseluruhan, mayoritas siswa di SMP Advent Menia, Kabupaten Sabu Raijua, NTT berada dalam kategori jarang untuk setiap aspek pengukuran intensitas game online.

Tabel 3. Intensitas Bermain Game Online Siswa SMP

\begin{tabular}{lcc}
\hline $\begin{array}{l}\text { Intensitas bermain } \\
\text { game online }\end{array}$ & Frekuensi & Persentase \\
\hline Rendah & 32 & 80 \\
Sedang & 8 & 20 \\
Tinggi & 0 & 0 \\
\hline Total & 40 & 100 \\
\hline
\end{tabular}

Data dari pengukuran pola aktivitas fisik (PAQ-A), yang kemudian disepadankan dengan klasifikasi pola aktivitas fisik yang dibagi menjadi lima, yaitu: (1) sangat tinggi, (2) tinggi, (3) sedang, (4) rendah, dan (5) sangat rendah. Berdasarkan tabel 3 terlihat bahwa $20 \%$ siswa memiliki kategori pola aktivitas fisik sedang dan $80 \%$ siswa memiliki kategori pola aktivitas fisik yang rendah. Dapat disimpulkan bahwa siswa SMP Advent Menia, Kabupaten Sabu Raijua, NTT memiliki pola aktivitas fisik yang tergolong rendah.

Tabel 4. Distribusi Pola Aktivitas Fisik Siswa SMP

\begin{tabular}{clcc}
\hline & & \multicolumn{2}{c}{ Frekuensi } \\
\cline { 3 - 4 } No & Kategori Pola Aktivitas Fisik & Absolut (f) & Persentase (\%) \\
\hline 1 & Sangat Tinggi & 0 & 0 \\
2 & Tinggi & 0 & 0 \\
3 & Sedang & 8 & 20 \\
4 & Rendah & 32 & 80 \\
5 & Sangat Rendah & 0 & 0 \\
\hline \multicolumn{2}{r}{ Total } & 40 & 100 \\
\hline
\end{tabular}

Dari perolehan hasil uji korelasi diperoleh nilai koefisien korelasi sebesar $-0,387^{*}$. Hasil tersebut bermakna bahwa terdapat hubungan yang signifikan antara variabel intensitas bermain game online dengan pola akitivitas fisik para siswa SMP Advent Menia, 
di Kabupaten Sabu Raijua, NTT dengan nilai $p=0,014$. Bentuk hubungan negatif pada koefisien korelasi $-0,387^{*}$ menunjukan hubungan kedua variabel bersifat sedang dan tidak searah. Hal tersebut berarti bahwa apabila variabel intensitas bermain game online mengalami peningkatan, maka variabel pola aktivitas fisik akan mengalami penurunan. Konflik dalam kehidupan pecandu berarti bahwa mereka akhirnya mengorbankan (i) hubungan pribadi mereka (misalnya, pasangan, anak-anak, kerabat, teman, dll.), (li) kehidupan belajar atau pendidikan (tergantung pada usia mereka), dan (iii) kegiatan sosial dan aktivitas fisik lainnya.

Tabel 5. Analisis Korelasi Intensitas Game Online dengan Pola Aktivitas Fisik

\begin{tabular}{lccc}
\hline & Uji Korelasi Spearman's rho & $\begin{array}{c}\text { Intensitas Bermain } \\
\text { Game Online }\end{array}$ & Pola Aktivitas Fisik \\
\hline \multirow{2}{*}{ Intensitas bermain game online } & Correlation Coefficient & 1.000 & $-.387^{*}$ \\
& Sig. (2-tailed) &. & .014 \\
& $\mathrm{~N}$ & 40 & 40 \\
\hline \multirow{2}{*}{ Pola Aktivitas Fisik } & Correlation Coefficient & $-.387^{*}$ & 1000 \\
& Sig. (2-tailed) & .014 &. \\
& $\mathrm{~N}$ & 40 & 40 \\
\hline
\end{tabular}

*Correlation is significant at the 0.05 level (2-tailed)

Makna dari hasil analisis korelasi menunjukkan bahwa terdapat cukup bukti untuk menolak hipotesis yang berbunyi: "terdapat hubungan yang signifikan antara intensitas bermain game online dengan pola aktivitas fisik siswa SMP Advent Menia, di Kabupaten Sabu, Rai Jua, Nusa Tenggara Timur.

\section{PEMBAHASAN}

Hasil penelitian ini menemukan bahwa $80 \%$ siswa SMP Advent Menia, Kabupaten Sabu Raijua, NTT memiliki intensitas bermain game online yang rendah dan sisanya $20 \%$ memiliki intensitas bermain game online yang sedang. Meskipun dalam distribusi intensitas bermain game online tidak terdapat siswa dengan intensitas bermain game online yang tinggi namun terdapat hubungan yang signifikan antara intensitas bermain game online dengan pola aktivitas fisik siswa SMP Advent Menia, Kabupaten Sabu Raijua, NTT setelah dilakukan uji analisis korelasi Spearman's Rho dengan nilai koefisien korelasi sebesar -0.387 dan taraf signifikansi sebesar 0.014 . Hal ini terlihat jelas pada distribusi tabel pola aktivitas fisik siswa yaitu $80 \%$ siswa memiliki pola aktivitas fisik yang rendah dan $20 \%$ siswa memiliki pola aktivitas fisik sedang. Sedangkan untuk kategori tinggi $0 \%$, sangat tinggi $0 \%$, dan sangat rendah $0 \%$. Sehingga dapat disimpulkan semakin tinggi intensitas bermain game online maka semakin rendah pola aktivitas fisik siswa SMP Advent Menia, Kabupaten Sabu Raijua, NTT dan sebaliknya.

Hasil dalam penelitian ini sejalan dengan hasil penelitian yang diungkapkan oleh Effendi (2014), yang meneliti tentang pengaruh penggunaan teknologi informasi terhadap aktivitas fisik dengan koefisien korelasi sebesar -,717 dan taraf signifikansi 0,000. Lebih lanjut Effendi menyebutkan, dalam penelitiannya faktor teknologi informasi mempengaruhi (koefisien determinasi) penurunan aktifitas fisik sebesar 51,41\%. Effendi juga mengungkapkan bahwa korelasi antara teknologi informasi dan aktivitas fisik merupakan korelasi tidak searah, yang apabila terjadi peningkatan pada salah satu 
variabel maka variabel yang lain akan mengalami penurunan.

Dalam penelitiannya, Danforth (2007), menyebutkan bahwa frekuensi bermain game online yang terlalu sering dapat mengacaukan kehidupan sehari-hari. Suryanto (2015) menjelaskan bahwa kecanduan game online dapat mengakibatkan Berat badan menurun karena lupa makan, atau bisa juga bertambah karena banyak ngemil dan kurang olahraga. Mudah lelah ketika melakukan aktivitas fisik, kesehatan tubuh menurun akibat kurang olahraga. Yang paling parah adalah dapat mengakibatkan kematian. Hal serupa juga dikemukakan oleh Fauziah (2013) yaitu intensitas bermain game online yang tidak terkontrol dapat berdampak buruk bagi remaja. Dampak negatif yang dapat muncul antara lain adalah sulitnya berkonsentrasi dan kurangnya aktivitas fisik.

Penelitian yang dilakukan oleh Krista Surbakti (2017), menyebutkan bahwa intensitas bermain game online yang tinggi dapat menyebabkan penyakit-penyakit seperti eye strain, ambeien, dan carpal tunnel syndrome. Lebih lanjut Krista Surbakti menyebutkan bahwa intensitas bermain game online yang tinggi dapat menyebabkan menurunnya metabolisme tubuh. Hal ini disebabkan oleh kurangnya aktivitas fisik sehingga mengurangi kerja otot dan pengeluaran energi. Dalam jangka panjang, dapat menyebabkan penurunan massa otot, kegemukan, dan menurunnya daya tahan tubuh.

Ni Putu Ayu Windari Putri (2019), dalam penelitiannya tentang hubungan bermain game online dan kebugaran fisik pada remaja, menyebutkan bahwa ada hubungan yang signifikan antara perilaku bermain game online dan kebugaran fisik remaja. Meskipun kebugaran fisik seseorang dapat dipengaruhi oleh banyak faktor seperti usia, jenis kelamin, dan genetik. Namun, aktivitas fisik juga merupakan faktor penting dalam menjaga kebugaran fisik, seperti yang diungkapkan oleh Widodo dan Kusnani (2013), bahwa aktivitas fisik dapat meningkatkan kesehatan apabila dilakukan dengan terukur dan teratur.

Menurut Owen (2010), penurunan aktivitas fisik dapat terjadi pada orang yang memiliki gaya hidup sedentary. Sedentary lifestyle merupakan suatu gaya hidup dimana seseorang lebih sering duduk, berbaring dan melakukan aktivitas yang sedikit membutuhkan energi. Sebagai contoh individu yang memiliki gaya hidup sedentary yaitu para pemain game online memiliki kecenderungan duduk dalam jangka waktu yang cukup lama. Hal ini didukung oleh penelitian Tremblay (2010) pada remaja (usia 12 sampai 19 tahun) mengenai sedentary lifestyle diperoleh hasil bahwa pada responden yang memiliki durasi menatap layar televisi atau komputer selama minimal lima jam per hari memiliki peningkatan tiga kali lebih besar kemungkinan untuk mengalami metabolik sindrom dibandingkan dengan responden yang memiliki durasi selama kurang lebih satu jam per hari.

Rendahnya aktivitas fisik dapat berarti pengeluaran energi yang kurang juga, sehingga asupan energi yang tidak diimbangi dengan pengeluaran energi dapat menyebabkan obesitas atau kegemukan maupun gangguan kesehatan lain. Sehingga sangat penting bagi remaja untuk melakukan aktivitas fisik yang cukup. Tidak hanya itu, kesadaran dalam diri seseorang dalam pengambilan keputusan dan tindakan dapat menuju pada perilaku hidup sehat. Hal ini diharapkan dapat diterapkan pada remaja yang bermain game online dengan intensitas tinggi maupun rendah sehingga menuntun pada perilaku promosi kesehatan remaja tersebut. Dengan melibatkan remaja dalam pengambilan keputusan, edukasi kecanduan game online dan pentingnya aktivitas fisik, diharapkan dapat mencegah kecanduan game online. 


\section{KESIMPULAN}

Kesimpulan yang diperoleh dari hasil penelitian ini adalah:

1. Siswa SMP bermain game online dengan intensitas yang rendah sebanyak $80 \%$ dan pada kategori sedang sebanyak $20 \%$.

2. Siswa SMP didapati $80 \%$ memiliki pola aktivitas fisik yang rendah dan hanya

\section{SARAN}

Temuan dalam penelitian ini dapat dijadikan data dasar untuk kemudian dijadikan informasi ilmiah dan bahan penyuluhan, baik kepada mahasiswa Fakultas IImu Keperawatan maupun dalam kegiatan pelayanan masyarakat, khususnya kepada kelompok masyarakat usia remaja tentang

\section{DAFTAR PUSTAKA}

Achmad Ibrahim, 2019. "Hubungan Bermain Game Online Remaja dengan Komunikasi Interpersonal Remaja dan Interaksi Sosial Remaja". (Skripsi). Universitas Airlangga.

American Psychiatric Association. (2013). Diagnostic and Statistical Manual of Mental Disorders (5th ed.).Washington, DC: Author.

Andina, E. (2019). "Pencegahan Kecanduan Gim Daring Pada Anak" eJournal Bidang Kesejahteraan Sosial vol.11 no.21. Pusat Penelitian Badan Keahlian DPR RI.

APJII. (2014). Google. Dipetik Januari 11, 2020, dari http://Asosiasi\%20 Penyelenggara\%20Jasa\%20Internet \%20 Indonesia.htm

APJII. (2018). Asosiasi Penyelenggara Jasa
$20 \%$ yang memiliki pola aktivitas fisik sedang.

3. Terdapat hubungan yang signifikan antara intensitas bermain game online dengan pola aktivitas fisik pada siswa SMP Advent Menia, Kabupaten Sabu Raijua, NTT dengan nilai $r^{2}=0,387$ dan nilai $p=0,014$.

pentingnya aktivitas fisik dan pengambilan keputusan dalam menjalankan pola hidup sehat. Temuan dalam penelitian ini diharapkan dapat dijadikan landasan data untuk dikembangkan dalam perumusan pendekatan asuhan keperawatan komunitas dan keluarga terkait pencegahan obesitas dan kecanduan game online pada remaja, pada penelitian berikutnya.

Internet Indonesia, pp. 1-7.

Billieux, J., Maurage, P., Lopez-Fernandez, O., Kuss, D. J. \& Griffiths, M.D. (2015).Can disordered mobile phone use be considered a behavioral addiction? An update on current evidence and a comprehensive model for future research. Current Addiction Reports,2, 154-162.

Danforth, I. D. W. 2007. Distinguishing Addiction and High Engagement In The Context Of Online Game Playing. Computers in Human Behaviour, 23, 1531-1548.

Erwinanto Dion (2017). "Hubungan Antara Tingkat Aktivitas Fisik Dengan Kebugaran Jasmani Siswa Kelas X Tahun Ajaran 2016/2017 Di Smk Muhammadiyah 1 Wates Kabupaten Kulon Progo Diy" (SKRIPSI) Fakultas IImu Keolahragaan Universitas Negeri Yogyakarta. 
Fauziah E.R. (2013). Pengaruh Game Online Terhadap Perubahan Perilaku Anak SMP Negeri 1 Samboja. eJournal Imu Komunikasi, 2013, 1 (3): $1-16$

Fauziah E.R. (2013). Pengaruh Game Online Terhadap Perubahan Perilaku Anak SMP Negeri 1 Samboja. eJournal Imu Komunikasi, 2013, 1 (3): 1-16

Griffiths, M. D. (2002). Gambling and gaming addictions in adolescence. Leicester: British Society/Blackwells.

Psychological

Krista Surbakti (2017). Pengaruh Game Online Terhadap Remaja. Jurnal Curere. Vol. 01, No. 01, April 2017, p-ISSN : 2597-9507, e-ISSN: 25979515.

Ni Putu Ayu Windari Putri, Luh Putu Ratna Sundari (2019). Hubungan Antara aktivitas Bermain Game Online Dengan Kebugaran Fisik Pada Remaja SMP Di Kota Denpasar. Jurnal MEDIKA UDAYANA, VOL. 8 NO.7,JULI, 2019. ISSN: 2597-8012.

Owen N, Sparling PB, Healy GN, Dunstan DW, Matthews CE (2010). Sedentary Behaviour: Emerging Evidence For A New Health Risk. Mayo Foundation For Medical Education And Research. 2010.85(12):1138-1141.

Tjibeng., Tiatri, S., Jaya, E. S., \& Suteja, M. S. (2013). The development of Indonesian online game addiction questionnaire. PLoS ONE, 8(4), 4-8. doi: $10.1371 /$ journal.pone.0061098

Tremblay MS, Colley RC, Saunders TJ, Healy GN, Owen N (2010). Physiological and Health Implications of A Sedentary Lifestyle.NRC Research Press. 2010. 35: 725-740 